\title{
Occasional soil tillage, liming, and nitrogen fertilization on long-term no-tillage system
}

\author{
Renato Yagi $(1)$ \\ (1)Instituto Agronômico do Paraná, Polo Regional de Pesquisa de Ponta Grossa, Rodovia do Café, Km 496, Avenida Presidente Kennedy, \\ s/no, Caixa Postal 129, CEP 84001-970 Ponta Grossa, PR, Brazil. E-mail: ryagi@iapar.br
}

\begin{abstract}
The objective of this work was to evaluate the residual effects of occasional soil tillage in a 17-year-old, no-tillage system, associated with liming and nitrogen fertilization, on the crop yields and chemical properties of a very clayey Oxisol in the South of Brazil. A randomized complete block design in split-split plots was used, with two soil managements (with or without plowing), two liming treatments (with or without the required dose to raise base saturation to $70 \%)$, five $\mathrm{N}$ doses applied on side-dress $(0,1,2,4$, and 6 times the recommended amounts), and four replicates. A rotation system was used with corn and soybean in the summer, and with wheat and black oats in the winter. The residual effects of occasional soil tillage in a consolidated no-tillage system do not supplant those of liming applied on soil surface, in periods of water deficit, which subsidizes the recommendation to maintain the system consolidated. Excess $\mathrm{N}$ fertilization in no-tillage, with liming applied only on soil surface, may harm wheat yield, acidifying the topsoil and leaching $\mathrm{Mg}^{2+}$ to the subsurface soil layers. Without liming, soil acidification is more intense with $\mathrm{N}$ fertilization, which, however, favors the accumulation of organic matter on soil surface in a consolidated no-tillage system.
\end{abstract}

Index terms: consolidated no-tillage system, soil acidity, soil management, soil organic matter, superficial liming, water deficit.

\section{Revolvimento ocasional do solo, calagem e adubação nitrogenada sobre sistema plantio direto de longa duração}

Resumo - O objetivo deste trabalho foi avaliar os efeitos residuais do revolvimento ocasional do solo, em sistema plantio direto com 17 anos, associado a métodos de calagem e à adubação nitrogenada, sobre a produtividade das culturas e os atributos químicos de um Latossolo Vermelho distroférrico típico muito argiloso, no Sul do Brasil. Utilizou-se um delineamento de blocos ao acaso em parcelas subsubdivididas, com dois manejos de solo (com ou sem revolvimento do solo), dois tratamentos com calagem (com ou sem a dose necessária para elevar a saturação por bases a 70\%), cinco doses de $\mathrm{N}$ em cobertura $(0,1,2$, 4 e 6 vezes as quantidades recomendadas) e quatro repetições. Utilizou-se um sistema de rotação de milho e soja, no verão, e de trigo e aveia-preta, no inverno. Os efeitos residuais do revolvimento ocasional do solo em sistema plantio direto consolidado não suplantam os da calagem na superfície do solo, em períodos de deficit hídrico, o que subsidia a recomendação para manutenção do sistema consolidado. A adubação nitrogenada excessiva no plantio direto, com calagem aplicada apenas na superfície do solo, pode prejudicar o rendimento do trigo, com acidificação da camada superficial e lixiviação de $\mathrm{Mg}^{2+}$ para as camadas subsuperficiais do solo. Sem calagem, a acidificação do solo é mais intensa com a adubação nitrogenada, o que, no entanto, favorece o acúmulo de matéria orgânica na camada superficial do solo, em um sistema plantio direto consolidado.

Termos para indexação: plantio direto consolidado, acidez do solo, manejo do solo, matéria orgânica do solo, calagem superficial, deficit hídrico.

\section{Introduction}

After more than a decade in no-tillage system (NTS), occasional soil tillage can be used to decompress the soil, redistribute its fertility accumulated on the surface, correct its acidity with limestone incorporation (Fidalski et al., 2015), and control herbicide-resistant weeds (Kettler et al., 2000; Crawford et al., 2015); occasional soil tillage is conceptualized as a strategic soil tillage (Liu et al., 2016). However, crop yields have not shown significant variations immediately after the occasional tillage of a consolidated NTS of more than 10 years (Dang et al., 2015; Fidalski et al., 2015), supporting dogmatic recommendations for 
maintaining soil management under NTS without any kind of tillage.

The occasional soil tillage under consolidated NTS can neither have effect on soil organic carbon content (Crawford et al., 2015; Liu et al., 2016) nor substantially decrease it in the superficial layers (VandenBygaart \& Kay, 2004), or even increase it in the subsuperficial layers (Kettler et al., 2000; Gál et al., 2007). Moreover, disk plows on soil under consolidated NTS can eliminate the stratification of the chemical and physical attributes of the soil, and invert soil layers (Quincke et al., 2007; Fidalski et al., 2015). This practice, therefore, can increase the potential of the system to sequester atmospheric $\mathrm{C}$ by favoring the humification of organic $\mathrm{C}$ in the subsurface layer, exposing soil with less $\mathrm{C}$ to the surface (Quincke et al., 2007). However, more than two-thirds of the organic $\mathrm{C}$ of the subsurface layer of sandy soil accumulated over years of NTS can be lost with a single mechanical intervention (VandenBygaart \& Kay, 2004).

Organic N mineralization as a consequence of occasional soil tillage under NTS may also affect crop yields due to the release of $\mathrm{N}$ at greater soil depths, which are more accessible to plants under water deficit (Kettler et al., 2000). The cumulative losses of $\mathrm{CO}_{2}$ are similar between occasional tillage and continuous NTS, but peaks of gas release occur immediately after soil mobilization under NTS, in comparison to undisturbed soils (Quincke et al., 2007). Similarly, Kristensen et al. (2000) reported an initial release of $\mathrm{NO}_{3}{ }^{-}$two to three times higher after breaking the soil structure of a soil under NTS for 20 years. Therefore, with the incorporation of limestone into the soil under NTS, the efficiency of $\mathrm{N}$ fertilization may be lower than liming on the soil surface (Rosolem et al., 2003). Nonetheless, liming can interact with fertilization, even when applied on the soil surface of a consolidated NTS, making it more efficient for winter crops (Caires et al., 2015). Under these conditions, this practice can also increase soil $\mathrm{C}$ stocks due to the formation of cationic bridges with $\mathrm{Ca}^{2+}$ that stabilizes organic $\mathrm{C}$ in organomineral complexes (Inagaki et al., 2016).

Surface applications and limestone incorporations in the soil after 9 and 12 years of NTS (Ciotta et al., 2004), and after 11, 12, and 13 years (Wortmann et al., 2010), did not result in differences in the soil organic $C$ content. Fidalski et al. (2015) did no report differences between treatments for the organic $\mathrm{C}$ content in the superficial layer of a 17-year-old NTS, after six months of superficial or incorporated applications of limestone, but $11 \%$ increase of organic $\mathrm{C}$ content at 0.1 to $0.2 \mathrm{~m}$ soil depths. Therefore, it is possible that $\mathrm{N}$ fertilization levels, occasional soil tillage, and liming, interact significantly in a consolidated NTS, with consequences on wheat and corn yields and on soil chemical attributes.

The objective of this work was to evaluate the residual and cumulative effects of occasional soil tillage and liming on consolidated NTS, and their interactions with $\mathrm{N}$ fertilization levels on the organic $\mathrm{C}$ content and on soil attributes related to acidity and grain yields of subsequent crops, after 40 months of soil management.

\section{Materials and Methods}

The experiment was carried out at the Instituto Agronômico do Paraná (Iapar), in Pato Branco, in the southwest of Paraná state, Brazil $\left(26^{\circ} 07^{\prime} 16^{\prime \prime S}\right.$, $52^{\circ} 39^{\prime} 37^{\prime \prime} \mathrm{W}$, at $730 \mathrm{~m}$ altitude). The region has a $\mathrm{Cfb}$ climate, according to the Köppen-Geiger's classification. The experimental area had been maintained under NTS since 1998, with crop rotations in the summer and winter, primarily composed of corn, bean, soybean, wheat, and black oats. The experiment was set on a very clayey Rhodic Hapludox (Latossolo Vermelho distroférrico), with $1.28 \mathrm{~kg} \mathrm{dm}^{-3}$ soil bulk density, and $620 \mathrm{~g} \mathrm{~kg}^{-1}$ clay, $330 \mathrm{~g} \mathrm{~kg}^{-1}$ silt, and $50 \mathrm{~g} \mathrm{~kg}^{-1}$ sand (Claessen, 1997). The chemical analysis (Pavan et al., 1992) showed: $23 \mathrm{~g} \mathrm{dm}^{-3}$ organic $\mathrm{C}$; $\mathrm{pH}\left(\mathrm{CaCl}_{2}\right), 4.8 ; 24 \mathrm{~g} \mathrm{dm}^{-3} \mathrm{P}$ in Mehlich-1; $4.79 \mathrm{cmol}_{\mathrm{c}} \mathrm{dm}^{-3} \mathrm{Ca} ; 2.10 \mathrm{cmol}_{\mathrm{c}} \mathrm{dm}^{-3} \mathrm{Mg} ; 0.16 \mathrm{cmol}_{\mathrm{c}} \mathrm{dm}^{-3}$ $\mathrm{K} ; 5.25 \mathrm{cmol}_{\mathrm{c}} \mathrm{dm}^{-3}$ potential acidity $(\mathrm{H}+\mathrm{Al}) ; 7.05 \mathrm{cmol}_{\mathrm{c}}$ $\mathrm{dm}^{-3}$ sum of bases; $12.3 \mathrm{cmol}_{\mathrm{c}} \mathrm{dm}^{-3}$ cation exchange capacity (CEC); and $57 \%$ base saturation index (V).

The average monthly rainfall and temperatures over the experimental period are depicted in Figure 1.

A randomized complete block design was used in split-split plots, with four replicates. In the plots, the treatments with or without, occasional soil tillage after 17-year-old NTS were evaluated, using a $0-0.2 \mathrm{~m}$ depth disk plowing (32" disk diameter) of a dried out fodder turnip (Raphanus sativus L.), followed by two disking with 14" diameter (10/13/2009). In the subplots, 0 and 1.7 $\mathrm{Mg} \mathrm{ha}^{-1}$ dolomitic limestone (100\% total neutralizing power, $32 \% \mathrm{CaO}, 18 \% \mathrm{MgO}$ ) were evaluated. The 1.7 $\mathrm{Mg} \mathrm{ha}{ }^{-1}$ dose is the recommended one to raise base 
saturation index to $70 \%$ in the soil. In the subsubplots, $\mathrm{N}$ fertilization levels were applied $0,1,2,4$, and 6 times the recommended amount of $\mathrm{N}$ for corn and wheat crops (Oliveira, 2003). After the application of the treatments, corn (2009/2010), black oats (2010), soybean (2010/2011), wheat (2011), and corn (2011/2012) were cultivated.

The subsubplots had $44.1 \mathrm{~m}^{2}$ each, containing seven $7 \mathrm{~m}$ lines, spaced at $0.9 \mathrm{~m}$ apart, with carriers of $1 \mathrm{~m}$ between them, and $2 \mathrm{~m}$ between blocks. Spacing at 3.5 $m$ dividing two blocks on each side was used to improve feasibility and minimize the transit of machinery in the plots. The immediate effects of treatments with soil tillage and liming for corn (2009/2010), black oats (2010), and soybean (2011/2012) crops were reported by Fidalski et al. (2015).

Black oats did not receive fertilization; however, corn (2009/2010) was fertilized with $25 \mathrm{~kg} \mathrm{ha}^{-1} \mathrm{~N}, 50 \mathrm{~kg} \mathrm{ha}^{-1}$ $\mathrm{P}_{2} \mathrm{O}_{5}$, and $50 \mathrm{~kg} \mathrm{ha}^{-1} \mathrm{~K}_{2} \mathrm{O}$, according to Oliveira (2003), and soybean (2010/2011) was fertilized (Oliveira et al., 2007) with $80 \mathrm{~kg} \mathrm{ha}^{-1} \mathrm{~N}$ (at sowing) and $40 \mathrm{~kg} \mathrm{ha}^{-1} \mathrm{P}_{2} \mathrm{O}_{5}$ and $\mathrm{K}_{2} \mathrm{O}$. Wheat and corn fertilizations, as well as the applied levels of $\mathrm{N}$, were based on the protocol outlined by Oliveira (2003).

The wheat 'IPR 144' was cultivated in plots of $0.17 \mathrm{~m}$ row spacing and 4,000,000 plants $\mathrm{ha}^{-1}$, fertilized with $15 \mathrm{~kg} \mathrm{ha}^{-1} \mathrm{~N}$, and $30 \mathrm{~kg} \mathrm{ha}^{-1} \mathrm{P}_{2} \mathrm{O}_{5}$ and $\mathrm{K}_{2} \mathrm{O}$ at sowing $(06 / 15 / 2011)$, approximately 20 months after the occasional soil tillage and liming. Then, corn hybrid P30F53 was cultivated in plots of $0.90 \mathrm{~m}$ spacing, with a stand of 60,000 plants ha-1, fertilized with $25 \mathrm{~kg} \mathrm{ha}^{-1}$ $\mathrm{N}, 50 \mathrm{~kg} \mathrm{ha}^{-1} \mathrm{P}_{2} \mathrm{O}_{5}$, and $50 \mathrm{~kg} \mathrm{ha}^{-1} \mathrm{~K}_{2} \mathrm{O}$, at sowing (10/20/2011). Side-dressing levels of $\mathrm{N}$ were $0,45,90$, 180 , and $270 \mathrm{~kg} \mathrm{ha}^{-1}$ for wheat, and $0,60,120,240$ and $360 \mathrm{~kg} \mathrm{ha}^{-1}$ for corn, using urea.

The useful plots for wheat were $12.8 \mathrm{~m}^{2}$ and, for corn, $13.5 \mathrm{~m}^{2}$. Grain yields were standardized at $13 \%$ moisture. After corn cultivation, on 4/15/2012, about 30 months after the application of the main and secondary treatments, soil samples were collected from the 80 subsubplots, at $0-0.1$ and $0.1-0.2 \mathrm{~m}$ soil depths, taking composite samples for each layer, composed of 10 individual samples. Samples were air-dried, shaded, sieved $(0.02 \mathrm{~mm})$, and subjected to C (Walkley \& Black), $\mathrm{pH}\left(\mathrm{CaCl}_{2}\right), \mathrm{Ca}$, and $\mathrm{Mg}(\mathrm{KCl})$ analyses, as described in Pavan et al. (1992).

After verifying the normality of the data and the homoscedasticity of the variances, the results were subjected to analysis of variance at $5 \%$ of probability. The effects of the main and secondary treatments were deployed at each level of $\mathrm{N}$ fertilization, and interactions were evaluated by the Tukey's test, at $5 \%$ probability, to compare the means, and polynomial regressions at 5 and $1 \%$ were used to evaluate the quantitative factors ( $\mathrm{N}$ levels). These same criteria were used to evaluate

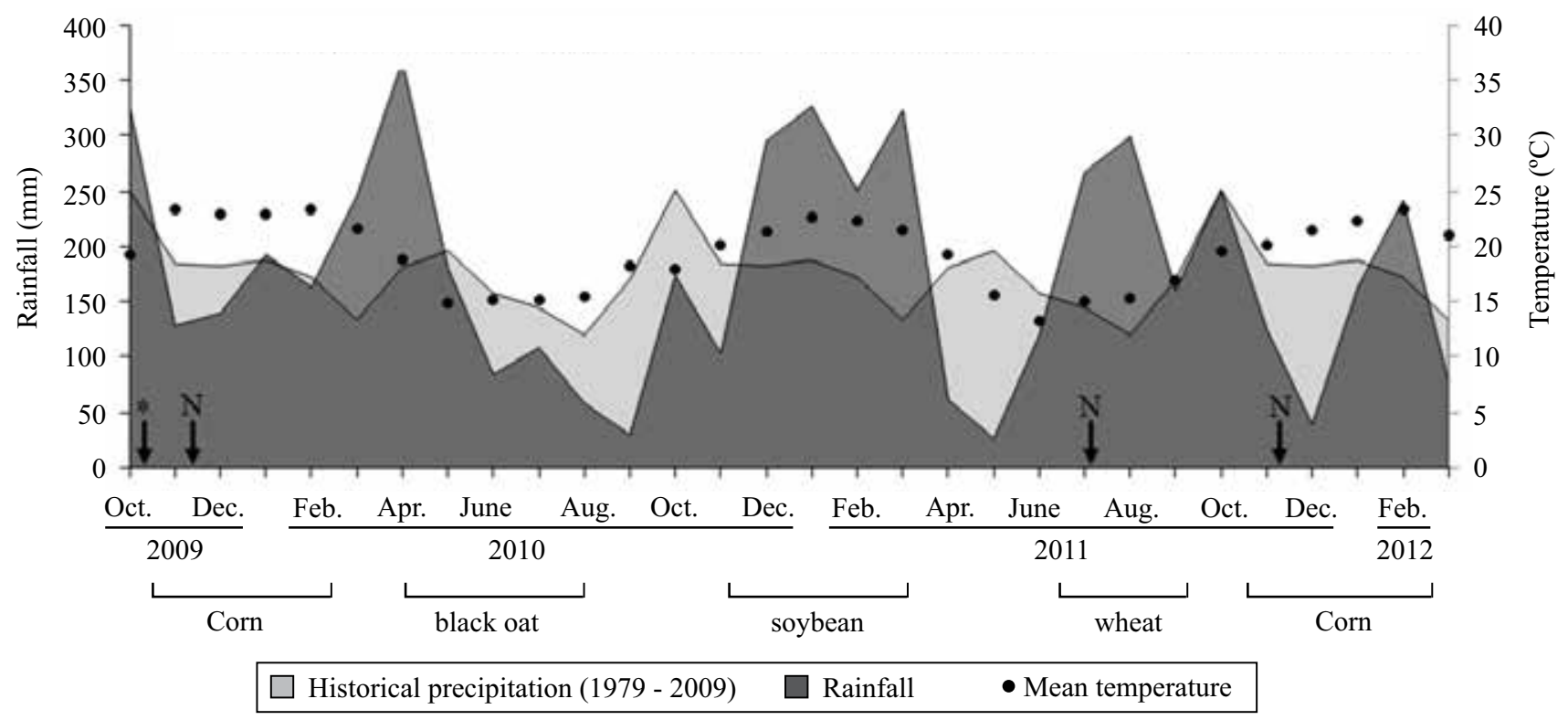

Figure 1. Average monthly rainfall and air temperatures over the experimental period, and historical precipitation from 1979 to 2009 . *Occasional soil tillage + liming; N, nitrogen side-dress fertilizations. 
the soil chemical properties, for each sampling depth. Pearson correlation coefficients were calculated between dependent variables of the main and secondary treatments. Statistical analyses were performed using the Agroestat software (Barbosa \& Maldonado Júnior, 2009).

\section{Results and Discussion}

Wheat grain yields decreased linearly with $\mathrm{N}$ application levels, when limestone was incorporated in the consolidated NTS, reaching $14.5 \%$ loss $\left(400 \mathrm{~kg} \mathrm{ha}^{-1}\right)$ at the maximum $\mathrm{N}$ level (Figure 2). Soil acidification by $\mathrm{N}$ fertilization could be the cause of the reduced grain yields, as suggested by Caires et al. (2015), who also observed linear decreases of wheat yields, which were, nonetheless, alleviated with higher-soil-surface liming levels in NTS. The $\mathrm{pH}\left(\mathrm{CaCl}_{2}\right)$ showed a negative quadratic response to $\mathrm{N}$ levels, under occasional soil tillage and liming treatments, and a linear negative response without liming (Table 1).
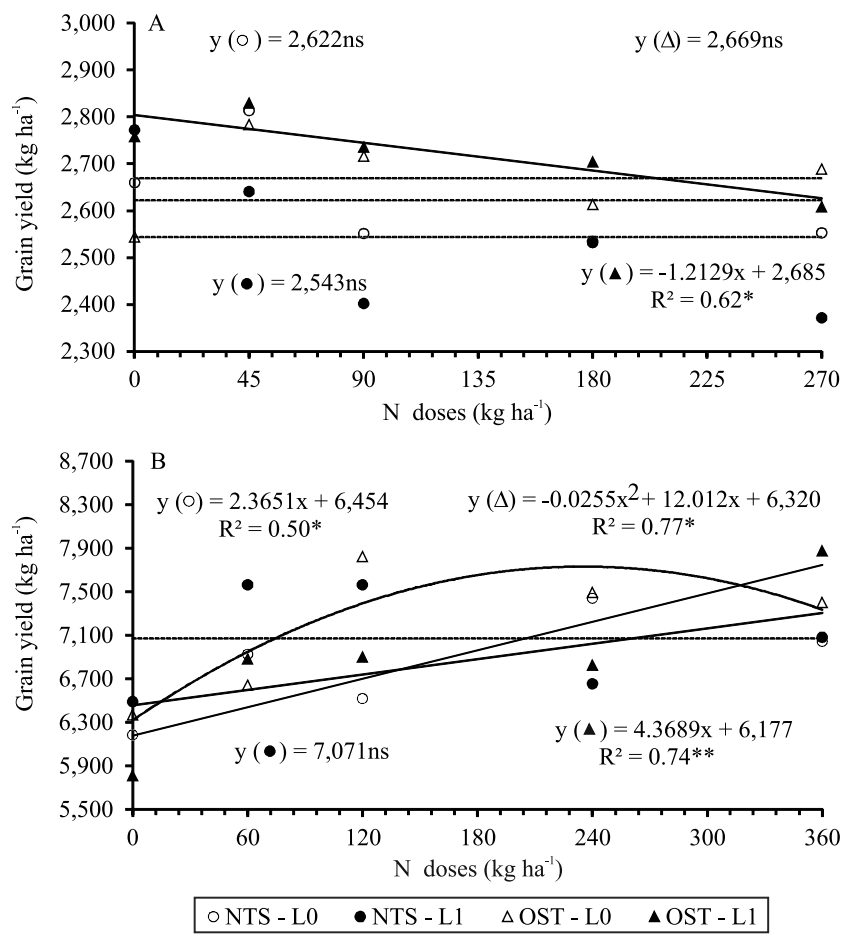

Figure 2. Wheat (A) and corn (B) grain yields as a function of $\mathrm{N}$ doses, in a 17-year no-tillage system (NTS), and in a NTS with occasional soil tillage (OST), with liming (L1), and without (L0) liming. *** Significant at 1 and 5\%, respectively.
Another possibility for the reduced wheat yield observed may be the linear decreases of $\mathrm{Mg}$ contents with the application of $\mathrm{N}$ levels, which reached approximately $22.1 \%$. Excess rainfall in the winter of 2011 (Figure 1), associated to the greater nitrate levels from $\mathrm{N}$ fertilization, and to the greater repulsion of this anion by the soil colloids with liming, may be the cause of the greater $\mathrm{Mg}^{2+}$ leaching in this treatment (Crusciol et al., 2011). The correlation between wheat grain yield and $\mathrm{Mg}^{2+}$ levels was significant $\left(\mathrm{r}=0.53^{* *}\right)$ at $0-0.1 \mathrm{~m}$ soil depth, which corroborates the observations of Kramer et al. (2014) of a positive correlation between wheat grain yields and $\mathrm{Mg}^{2+}$ levels at $0-0.1 \mathrm{~m}$ soil depth. Caires et al. (2015) reported linear decreases in $\mathrm{Mg}^{2+}$ content at the soil surface with liming, and stipulated that increasing amounts of $\mathrm{Mg}^{2+}$ leached below $0.6 \mathrm{~m}$ soil depth, in treatments with 4,8 , and 12 $\mathrm{Mg} \mathrm{ha}^{-1}$ of lime, associated with $180 \mathrm{~kg} \mathrm{ha}^{-1} \mathrm{~N}$.

No wheat grain losses were observed with $\mathrm{N}$ fertilization in the treatment with occasional soil tillage without liming (Table 1).

Table 1. Polynomial regressions for soil organic $\mathrm{C}$ levels, $\mathrm{pH}\left(\mathrm{CaCl}_{2}\right)$ values, and $\mathrm{Ca}^{2+}$ and $\mathrm{Mg}^{2+}$ contents, according to $\mathrm{N}$ doses in a non-tillage system (NTS), with or without occasional soil tillage (OST), and with (L1) or without (L0) liming.

\begin{tabular}{|c|c|c|}
\hline \multirow[t]{2}{*}{ Treatment } & \multicolumn{2}{|l|}{ Soil depth } \\
\hline & $0-0.1 \mathrm{~m}$ & $0.1-0.2 \mathrm{~m}$ \\
\hline & \multicolumn{2}{|l|}{ Organic $\mathrm{C}\left(\mathrm{mg} \mathrm{dm}^{-3}\right)$} \\
\hline NTS - L0 & $y=-0.83 x^{2}+5.32 x+45.36\left(R^{2}=0.86^{*}\right)$ & $\mathrm{y}=26.2^{\mathrm{ns}}$ \\
\hline NTS - L1 & $\mathrm{y}=27.3^{\mathrm{ns}}$ & $\mathrm{y}=25.7^{\mathrm{ns}}$ \\
\hline OST - L0 & $\mathrm{y}=29.5^{\mathrm{ns}}$ & $\mathrm{y}=27.3^{\mathrm{ns}}$ \\
\hline \multirow[t]{2}{*}{$\mathrm{OST}-\mathrm{L} 1$} & $\mathrm{y}=30.3^{\mathrm{ns}}$ & $\mathrm{y}=28.8^{\mathrm{ns}}$ \\
\hline & \multicolumn{2}{|l|}{$\mathrm{pH}\left(\mathrm{CaCl}_{2}\right)$} \\
\hline NTS - L0 & $\mathrm{y}=-0.04 \mathrm{x}+4.67\left(\mathrm{R}^{2}=0.81 * *\right)$ & $\mathrm{y}=4.7^{\mathrm{ns}}$ \\
\hline NTS - L1 & $\mathrm{y}=4.6^{\mathrm{ns}}$ & $\mathrm{y}=4.8^{\mathrm{ns}}$ \\
\hline OST - L0 & $\mathrm{y}=0.02 \mathrm{x}^{2}-0.17 \mathrm{x}+4.59\left(\mathrm{R}^{2}=0.89 * *\right)$ & $\mathrm{y}=4.6^{\mathrm{ns}}$ \\
\hline \multirow[t]{2}{*}{ OST - L1 } & $\mathrm{y}=-0.04 \mathrm{x}+4.62\left(\mathrm{R}^{2}=0.93 * *\right)$ & $\mathrm{y}=4.7^{\mathrm{ns}}$ \\
\hline & \multicolumn{2}{|l|}{$\mathrm{Ca}^{2+}\left(\mathrm{cmol}_{\mathrm{c}} \mathrm{dm}^{-3}\right)$} \\
\hline NTS - L0 & $y=-0.16 x+4.53\left(R^{2}=0.81 * *\right)$ & $\mathrm{y}=4.5^{\mathrm{ns}}$ \\
\hline NTS - L1 & $\mathrm{y}=4.1^{\mathrm{ns}}$ & $\mathrm{y}=4.1^{\mathrm{ns}}$ \\
\hline OST - L0 & $\mathrm{y}=3.4^{\mathrm{ns}}$ & $\mathrm{y}=3.9^{\mathrm{ns}}$ \\
\hline \multirow[t]{2}{*}{ OST $-\mathrm{L} 1$} & $y=-0.13 x+4.01\left(R^{2}=0.89 * *\right)$ & $\mathrm{y}=4.2^{\mathrm{ns}}$ \\
\hline & \multicolumn{2}{|l|}{$\mathrm{Mg}^{2+}\left(\mathrm{cmol}_{\mathrm{c}} \mathrm{dm}^{-3}\right)$} \\
\hline NTS - L0 & $\mathrm{y}=1.8^{\mathrm{ns}}$ & $\mathrm{y}=2.0^{\mathrm{ns}}$ \\
\hline NTS - L1 & $y=-0.08 x+2.16\left(R^{2}=0.91 *\right)$ & $\mathrm{y}=1.8^{\mathrm{ns}}$ \\
\hline OST - L0 & $\mathrm{y}=1.5^{\mathrm{ns}}$ & $\mathrm{y}=1.7^{\mathrm{ns}}$ \\
\hline OST - L1 & $\mathrm{y}=1.8^{\mathrm{ns}}$ & $\mathrm{y}=1.9^{\mathrm{ns}}$ \\
\hline
\end{tabular}

$* * *$ Significant at 1 and $5 \%$ probability, respectively. 
Corn yields increased $19.9 \%\left(1,302 \mathrm{~kg} \mathrm{ha}^{-1}\right)$ with occasional soil tillage without liming, at $120 \mathrm{~kg} \mathrm{ha}^{-1}$ $\mathrm{N}$, in comparison to continuous NTS without liming (Figure 3). There was a strong drought occurrence in the first corn crop season, as shown in the climatologic records (Figure 1), particularly one month after sowing that showed $78 \%$ less precipitation than the average of the 20 years prior to the experimental period. This resulted in a mean productivity of $6,975 \mathrm{~kg} \mathrm{ha}^{-1}$ of grains, $33.4 \%\left(3,503 \mathrm{~kg} \mathrm{ha}^{-1}\right)$ less than the average observed in the first corn crop in 2009/2010, harvested about four months after the application of treatments (Fidalski et al., 2015). These results are contrary to those reported by Debiasi et al. (2010), in which corn and soybean showed lower yields when the soil was subjected to mechanical scarification, since this practice lowered the final populations of the plants under water deficit. However, these authors also observed increases of soybean and corn yields with black oat and hairy vetch as winter crops, in comparison to fallow, and attributed this result to a better soil aggregation that resulted from greater soil organic matter content. Immediately after four months of the occasional soil tillage and liming, organic $\mathrm{C}$ contents increased 10.8\% at the 0.1-0.2 m soil depth (Fidalski et al., 2015), and after about 30 months, this difference changed to $7.4 \%$ $\left(1.9 \mathrm{~g} \mathrm{dm}^{-3} \mathrm{C}\right)$ (Table 1).

With the $\mathrm{N}$ dose of $120 \mathrm{~kg} \mathrm{ha}^{-1}$, which is recommended for $\mathrm{N}$ fertilization in corn after winter grass (Oliveira, 2003), limestone incorporation with the occasional

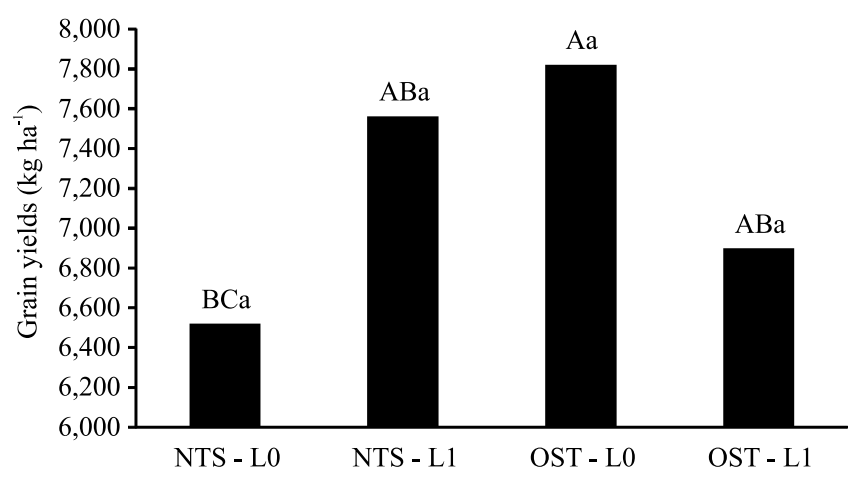

Figure 3. Effects on grain yields of corn (Zea mays) related to occasional soil tillage (OST) and continuous notillage system (NTS) with liming (L1), and without liming (L0), with $120 \mathrm{~kg} \mathrm{ha}^{-1} \mathrm{~N}$ as side-dress. Means followed by equal letters, upper case between soil managements, and lowercase between liming levels, do not differ by the Tukey's test, at 5\% probability. tillage produced as much as the treatment with the application on soil surface (Figure 2). Either to control weeds (Kettler et al., 2000; Crawford et al., 2015) to eliminate soil compaction, or to decrease fertility stratification on the topsoil (Fidalski et al., 2015), the immediate effects of occasional soil tillage on NTS with more than 10 years, on the yields of subsequent cultures, were null or negative. Therefore, the superficial liming and the maintenance of the continuity of the NTS allow the system to remain consolidated and still sustainable.

The incorporation of limestone with occasional tillage in consolidated NTS favored the linear increasing of corn yield $\left(\mathrm{R}^{2}=0.74 * *\right)$ with $\mathrm{N}$ fertilization (Figure 2), but no effect was observed for $\mathrm{N}$ fertilization with superficial liming in NTS, which had an average of 7,071 $\mathrm{kg} \mathrm{ha}^{-1}$. To reach this average, $205 \mathrm{~kg} \mathrm{ha}^{-1} \mathrm{~N}$ would be required in the treatment with lime incorporation, after about two and a half years from the occasional soil tillage. Rosolem et al. (2003) reported that the incorporation of limestone in deformed soil samples of a medium textured Oxisol resulted in a greater efficiency of $\mathrm{N}$ fertilization for cotton plants.

In NTS without liming, there was a quadratic effect of the $\mathrm{N}$ levels on the organic $\mathrm{C}$ contents at $0-0.1 \mathrm{~m}$ soil depth (Table 1), which reached a maximum of 34.8 $\mathrm{g} \mathrm{dm}^{-3} \mathrm{C}$ with 3.2 times the recommended $\mathrm{N}$ dose for corn and wheat crops, after 40 months. Caires et al. (2015) reported that annual side-dress applications of up to $180 \mathrm{~kg} \mathrm{ha}^{-1} \mathrm{~N}$ (ammonium nitrate) for winter crops (wheat and black oats) had no effect on the $\mathrm{C}$ content of a sandy soil cultivated under NTS. Nitrogen fertilization effect on soil $\mathrm{C}$ balance is still controversial. since, on one hand, $\mathrm{N}$ fertilization may favor dry matter yields and increase organic inputs to the soil, but, on the other hand, it also favors the mineralization of the soil organic matter. These facts turns $\mathrm{C}$ sequestration by soils with $\mathrm{N}$ fertilization a myth, according to Khan et al. (2007). Nonetheless, $\mathrm{N}$ fertilization can increase $\mathrm{C}$ contents in humic acids, which, in turn, may be a prerequisite for increased $\mathrm{C}$ content in the clay fraction, stabilizing organic $\mathrm{C}$ contents in the soil due to the recalcitrance of this fraction (Yagi et al., 2005). Poirier et al. (2009) reported a greater residue accumulation on soil surface with high-N rates, under NTS, which favored soil organic matter accumulation at $0-0.2 \mathrm{~m}$ soil depth, mainly in the $0-0.05 \mathrm{~m}$ layer. Contrastingly, 
under conventional tillage, $\mathrm{N}$ fertilization is associated to a decrease of soil organic matter contents.

The increase of organic $\mathrm{C}$ contents with $\mathrm{N}$ fertilization was not expected in the short period of evaluation (40 months), particularly because there was no effect of $\mathrm{N}$ levels on shoot dry matter yield of the crops over time in the consolidated NTS without liming.

Nitrogen levels had different effects on $\mathrm{pH}\left(\mathrm{CaCl}_{2}\right)$ values and on $\mathrm{Ca}^{2+}$ and $\mathrm{Mg}^{2+}$ levels at $0-0.1 \mathrm{~m}$ soil depth, with the different soil managements and liming levels (Table 1). In soils under occasional tillage and liming, at $0-0.1 \mathrm{~m}$ depth, there was a quadratic effect of $\mathrm{N}$ levels on the $\mathrm{pH}$ values $\left(\mathrm{CaCl}_{2}\right)$, but a linear decrease with soil tillage without liming.

The application of limestone to the soil increased the $\mathrm{pH}\left(\mathrm{CaCl}_{2}\right)$ values only in the treatment with occasional soil tillage (Figure 4). There were no differences of the $\mathrm{pH}\left(\mathrm{CaCl}_{2}\right)$ values at $0.1-0.2 \mathrm{~m}$ soil depth with the
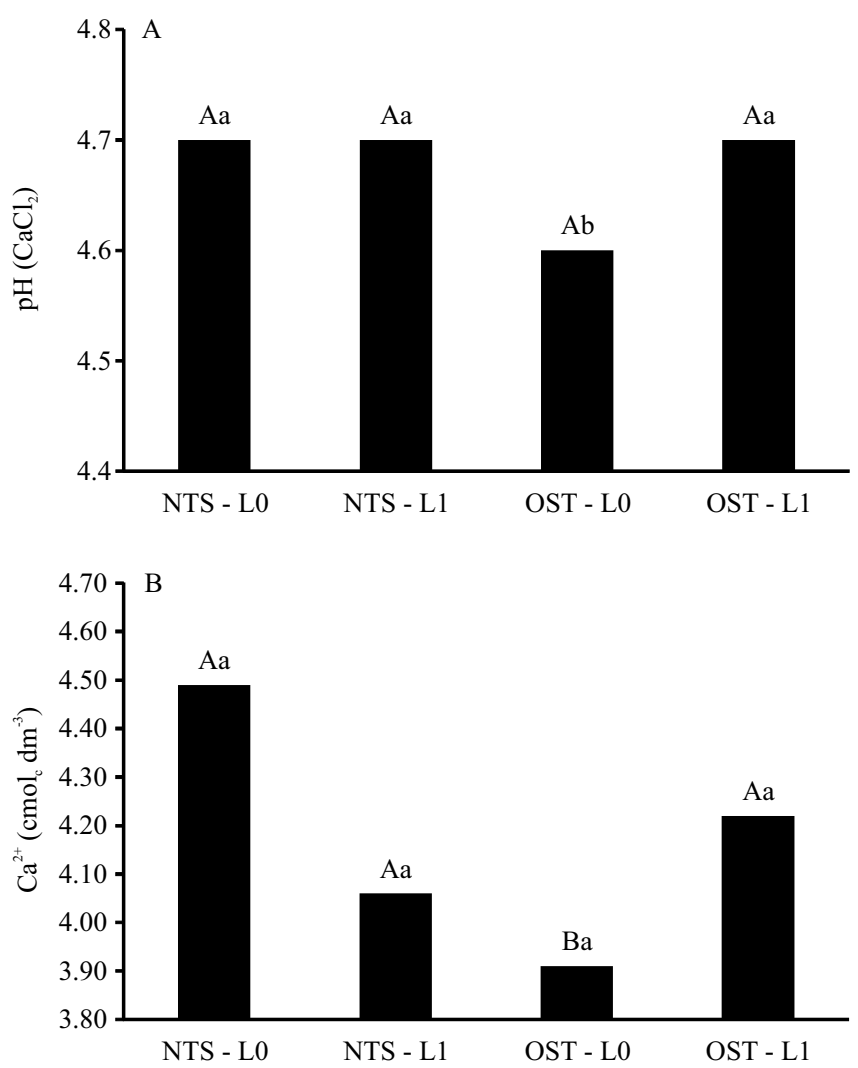

Figure 4. Effects of occasional soil tillage (OST) and continuous no-tillage system (NTS) with liming (L1), and without liming ( $\mathrm{L} 0)$, on $\mathrm{pH}\left(\mathrm{CaCl}_{2}\right)$ values (a) e $\mathrm{Ca}^{2+}$ contents (b) at 0,1-0,2 m soil depth. Means followed by equal letters, upper case between soil managements and lowercase between liming levels, do not differ by Tukey's test, at $5 \%$ probability. occasional tillage, with or without liming. However, at this layer, the superficial application of limestone in NTS increased these $\mathrm{pH}$ values in 0.1 unit. The occasional soil tillage acidified the soil layer from 0 to $0.1 \mathrm{~m}$ depth, reaching minimum $\mathrm{pH}\left(\mathrm{CaCl}_{2}\right)$ values of 4.2 and 4.4, with the $\mathrm{N}$ doses of 4.4 and 6.0 times the recommended amount, respectively (Table 1).

\section{Conclusions}

1. The residual effects of occasional soil tillage in a long term no-tillage system do not supplant those of liming at the soil surface, in a period of water deficiency, which subsidizes the recommendation to maintain the system consolidated.

2. Excess $\mathrm{N}$ fertilization in no-tillage system with liming on soil surface may harm wheat grain yields, with the acidification of the topsoil and $\mathrm{Mg}^{2+}$ leaching to subsurface soil layer.

3. Without liming, $\mathrm{N}$ fertilization intensifies the soil acidification, but also favors organic matter accumulation on the soil surface of a consolidated notillage system.

\section{Acknowledgments}

To Eloir Myszka, agricultural technician, for technical support.

\section{References}

BARBOSA， J.C.; MALDONADO JÚNIOR，W. Software AgroEstat: sistema de análises estatísticas de ensaios agronômicos. Jaboticabal: Universidade Estadual Paulista, 2009.

CAIRES, E.F.; HALISKI, A.; BINI, A.R.; SCHARR, D.A. Surface liming and nitrogen fertilization for crop grain production under no-till management in Brazil. European Journal of Agronomy, v.66, p.41-53, 2015. DOI: 10.1016/j.eja.2015.02.008.

CIOTTA, M.N.; BAYER, C.; ERNANI, P.R.; FONTOURA, S.M.V.; WOBETO, C.; ALBUQUERQUE, J.A. Manejo da calagem e os componentes da acidez de Latossolo Bruno em plantio direto. Revista Brasileira de Ciência do Solo, v.28, p.317-326, 2004. DOI: $10.1590 /$ S0100-06832004000200010.

CLAESSEN, M.E.C. (Org.). Manual de métodos de ánalise de solo. 2.ed. rev. e atual. Rio de Janeiro: EMBRAPA-CNPS, 1997. 212p. (EMBRAPA CNPS. Documentos, 1).

CRAWFORD, M.H.; RINCON-FLOREZ, V.; BALZER, A.; DANG, Y.P.; CARVALHAIS, L.C.; LIU, H.; SCHENK, P.M. Changes in the soil quality attributes of continuous no-till farming systems following a strategic tillage. Soil Research, v.53, p.263273, 2015. DOI: 10.1071/SR14216. 
CRUSCIOL, C.A.C.; GARCIA, R.A.; CASTRO, G.S.A.; ROSOLEM, C.A. Nitrate role in basic cation leaching under notill. Revista Brasileira de Ciência do Solo, v.35, p.1975-1984, 2011. DOI: 10.1590/S0100-06832011000600014.

DANG, Y.P.; MOODY, P.W.; BELL, M.J.; SEYMOUR, N.P.; DALAL, R.C.; FREEBAIRN, D.M.; WALKER, S.R. Strategic tillage in no-till farming systems in Australia's northern grains-growing regions: II. Implications for agronomy, soil and environment. Soil \& Tillage Research, v.152, p.115-123, 2015. DOI: 10.1016/j.still.2014.12.013.

DEBIASI, H.; LEVIEN, R.; TREIN, C.R.; CONTE, O.; KAMIMURA, K.M. Produtividade de soja e milho após coberturas de inverno e descompactação mecânica do solo. Pesquisa Agropecuária Brasileira, v.45, p.603-612, 2010. DOI: 10.1590/S0100-204X2010000600010.

FIDALSKI, J.; YAGI, R.; TORMENA, C.A. Revolvimento ocasional e calagem em Latossolo muito argiloso em sistema plantio direto consolidado. Revista Brasileira de Ciência do Solo, v.39, p.1483-1489, 2015. DOI: 10.1590/01000683rbcs20140428.

GÁL, A.; VYN, T.J.; MICHÉLI, E.; KLADIVKO, E.J.; MCFEE, W.W. Soil carbon and nitrogen accumulation with long-term notill versus moldboard plowing overestimated with tilled-zone sampling depths. Soil \& Tillage Research, v.96, p.42-51, 2007. DOI: $10.1016 /$ j.still.2007.02.007.

INAGAKI, T.M.; SÁ, J.C. de M.; CAIRES, E.F.; GONÇALVES, D.R.P. Lime and gypsum application increases biological activity, carbon pools, and agronomic productivity in highly weathered soil. Agriculture, Ecosystems and Environment, v.231, p.156165, 2016. DOI: 10.1016/j.agee.2016.06.034.

KETTLER, T.A.; LYON, D.J.; DORAN, J.W.; POWERS, W.L.; STROUP, W.W. Soil quality assessment after weed-control tillage in a no-till wheat-fallow cropping system. Soil Science Society of America Journal, v.64, p.339-346, 2000. DOI: 10.2136/ sssaj2000.641339x.

KHAN, S.A.; MULVANEY, R.L.; ELLSWORTH, T.R.; BOAST, C.W. The myth of nitrogen fertilization for soil carbon sequestration. Journal of Environmental Quality, v.36, p.18211832, 2007. DOI: 10.2134/jeq2007.0099.

KRAMER, L.F.M.; MÜLLER, M.M.L.; TORMENA, C.A.; GENÚ, A.M.; MICHALOVICZ, L.; VICENSI, M. Atributos químicos do solo associados à produtividade do trigo em um talhão com diferentes potenciais produtivos. Revista Brasileira de Ciência do Solo, v.38, p.1190-1199, 2014. DOI: 10.1590/S010006832014000400015.

KRISTENSEN, H.L.; MCCARTY, G.W.; MEISINGER, J.J. Effects of soil structure disturbance on mineralization of organic soil nitrogen. Soil Science Society of America Journal, v.64, p.371-378, 2000. DOI: 10.2136/sssaj2000.641371x.

LIU, H.; CRAWFORD, M.; CARVALHAIS, L.C.; DANG, Y.P.; DENNIS, P.G.; SCHENK, P.M. Strategic tillage on a Grey Vertosol after fifteen years of no-till management had no short-term impact on soil properties and agronomic productivity. Geoderma, v.267, p.146-155, 2016. DOI: 10.1016/j.geoderma.2016.01.002.

OLIVEIRA, E.L. de. (Coord.). Sugestão de adubação e calagem para culturas de interesse econômico no Estado do Paraná. Londrina: IAPAR, 2003. 30p. (IAPAR. Circular, 128). Available at: $\quad<$ http://www.iapar.br/arquivos/File/zip_pdf/ct_128.pdf $>$. Accessed on: Dec. 152015.

OLIVEIRA, F.A. de; SFREDO, G.J.; CASTRO, C. de; KLEPKER, D. Fertilidade do solo e nutrição da soja. Londrina: Embrapa Soja, 2007 (Embrapa Soja. Circular técnica, 50).

PAVAN, M.A.; BLOCH, M. de F.; ZEMPULSKI, H. da C.; MIYAZAWA, M.; ZOCOLER, D.C. Manual de análise química do solo e controle de qualidade. Londrina: Iapar, 1992. (IAPAR. Circular técnica, 76).

POIRIER, V.; ANGERS, D.A.; ROCHETTE, P.; CHANTIGNY, M.H.; ZIADI, N.; TREMBLAY, G.; FORTIN, J. Interactive effects of tillage and mineral fertilization on soil carbon profiles. Soil Science Society of America Journal, v.73, p.255-261, 2009. DOI: $10.2136 /$ sssaj2008.0006.

QUINCKE, J.A.; WORTMANN, C.S.; MAMO, M.; FRANTI, T.; DRIJBER, R.A. Occasional tillage of no-till systems: carbon dioxide flux and changes in total and labile soil organic carbon. Agronomy Journal, v.99, p.1158-1168, 2007. DOI: 10.2134/ agronj2006.0317.

ROSOLEM, C.A.; FOLONI, J.S.S.; OLIVEIRA, R.H. de. Dinâmica do nitrogênio no solo em razão da calagem e adubação nitrogenada, com palha na superfície. Pesquisa Agropecuária Brasileira, v.38, p.301-309, 2003. DOI: 10.1590/S0100204X2003000200018.

VANDENBYGAART, A.J.; KAY, B.D. Persistence of soil organic carbon after plowing a long-term no-till field in southern Ontario, Canada. Soil Science Society of America Journal, v.68, p.13941402, 2004. DOI: 10.2136/sssaj2004.1394.

WORTMANN, C.S.; DRIJBER, R.A.; FRANTI, T.G. One-time tillage of no-till crop land five years post-tillage. Agronomy Journal, v.102, p.1302-1307, 2010. DOI: 10.2134/agronj2010.0051.

YAGI, R.; FERREIRA, M.E.; CRUZ, M.C.P. da; BARBOSA, J.C.; ARAÚJO, L.A.N. de. Soil organic matter as a function of nitrogen fertilization in crop successions. Scientia Agricola, v.62, p.374-380, 2005. DOI: 10.1590/S0103-90162005000400011.

Received on April 9, 2017 and accepted on October 31, 2017 